\title{
Deoxyribonucleic Acid Sequence Relatedness Among Some Members of the Yeast Genus Hansenula
}

\author{
GAYLE B. FUSON, C. W. PRICE, † AND H. J. PHAFF \\ Department of Food Science and Technology, University of California, Davis, California 95616
}

\begin{abstract}
The evolutionary affinities among several morphologically and physiologically similar species of the ascogenous yeast genus Hansenula were studied by techniques of genome comparison. Among the organisms studied, two clusters of related strains were identified by deoxyribonucleic acid base composition and sequence relatedness. These clusters showed little relatedness to each other or to the other strains studied. Several strains of $H$. wingei, as well as the type strain of $H$. canadensis, exhibited 78 to $98 \%$ base sequence complementarity with the type strain of $H$. wingei. These species are all associated with coniferous trees. An additional strain of $H$. wingei shared $62 \%$ of its nucleotide sequences with the type strain. Three other yeasts resembling $H$. wingei but isolated from exudates of alder trees showed $>98 \%$ complementarity among themselves but $<10 \%$ relatedness to the $H$. wingei type. These strains are considered to represent a new species, $H$. alni. The results suggest the inadequacy of current taxonomic criteria and the need for new approaches to yeast systematics.
\end{abstract}

Genome comparison has elucidated the relationships among various groups of procaryotes, and it is now being employed increasingly in yeast systematics (cf. 10, 11). Recently we used this molecular approach to establish the evolutionary affinities among members of several ascogenous genera (14). In the present paper we apply this methodology to some members of the ascogenous genus Hansenula. Although this large and diverse genus has been extensively characterized by morphological, physiological, and ecological criteria (20), the natural relationships among the constituent species remain unclear. In addition, the taxonomic validity of the criteria that separate the species of Hansenula has not been satisfactorily demonstrated.

The current study focuses upon species placed by Wickerham (20) on lines three and four of his proposed evolutionary tree for Hansenula. Although these yeasts share substantial phenotypic similarity, they are presently classified in six separate species. They have been characterized, in addition to the conventional taxonomic system, by numerical analysis (4) and by cell wall structure (5). We became interested in these yeasts after isolating, in the Pacific Northwest, three strains that closely resembled $H$. wingei, one of the members of the group. This study was initiated to clarify relationships among the currently recognized species, and we provide evidence to confirm that the three new strains represent a novel species of Hansenula, H. alni,

\footnotetext{
$\dagger$ Present address: Department of Bacteriology and Immunology, University of California, Berkeley, CA 94720.
}

which is described in an accompanying paper (12).

\section{MATERIALS AND METHODS}

Organisms. The yeasts used in this study are shown in Table 1.

DNA purification. Cultivation of cells and the extraction and purification of whole-cell yeast DNA were as previously described (14). Briefly, DNA purification involved cell breakage, chloroform extractions, ethanol precipitations, enzyme treatments, hydroxylapatite chromatography, and cesium chloride density equilibrium centrifugation.

Determination of base composition. The guanine-plus-cytosine $(G+C)$ content of yeast nuclear DNA was calculated from the buoyant density in cesium chloride by using the equation of Schildkraut et al. (15), as previously described (14).

DNA reannealing reactions. Renaturation kinetics and sequence complementarity were determined by renaturation in $280 \mathrm{mM}$ PB (an equimolar mixture of mono- and dibasic sodium phosphate, $\mathrm{pH}$ 6.8) at $25^{\circ} \mathrm{C}$ below the thermal denaturation point of native homologous DNA, as described in detail earlier (14). Before reannealing, rapidly renaturing minor DNA species were removed from the ${ }^{32} \mathrm{P}$-labeled reference DNAs (14). After heterologous reannealing reactions, duplex molecules were separated from unreacted DNA with $140 \mathrm{mM} \mathrm{PB}$ at $60^{\circ} \mathrm{C}$, using the hydroxylapatite batch technique of Brenner et al. (2). The same PB molarity was used for thermal elution studies of duplex molecules, essentially as described by Brenner et al. (2). The data are presented as percentages of actual binding to hydroxylapatite (experimentally determined) and as percentages of relative binding (normalized to the homologous reaction). 
TABLE 1. Hansenula strains used

\begin{tabular}{|c|c|c|c|c|}
\hline \multirow{2}{*}{ Organism } & \multirow{2}{*}{ Isolation source } & \multicolumn{3}{|c|}{ Strain designation $^{a}$} \\
\hline & & UCD & CBS & NRRL \\
\hline Hansenula alni Phaff et al. 1978 & Exudate of Alnus rubra & $928 \mathrm{~A}^{b}$ & 6986 & \\
\hline H. alni & Exudate of $A$. rubra & $68-940$ & 6987 & \\
\hline H. $\alpha \ln i$ & Exudate of $A$. rubra & $68-985$ & 6988 & \\
\hline $\begin{array}{l}\text { H. beckii Wickerham } 1951 \text { (syn. Endo- } \\
\text { mycopsis bisporus (Beck) Dekker 1922) }\end{array}$ & Frass of Picea sp. & $74-68^{b}$ & 1890 & $\mathrm{Y}-1482$ \\
\hline $\begin{array}{l}\text { H. bimundalis Wickerham et Santa } \\
\text { Maria var. bimundalis } 1965 \ldots \ldots\end{array}$ & Frass of Pinus sylvestris & $71-33^{b}$ & 5642 & Y-5343 \\
\hline $\begin{array}{l}\text { H. bimundalis Wickerham et Santa } \\
\text { Maria var. americana Wickerham } 1965\end{array}$ & Frass of $P$. jeffreyi & $74-69^{b}$ & 5644 & $Y-2156$ \\
\hline H. canadensis Wickerham $1951 \ldots \ldots$ & Frass of $P$. resinosa & $74-71^{b}$ & 1922 & Y-1888 \\
\hline$H$. canadensis $\ldots \ldots \ldots$ & Frass of $P$. strobus & $74-72$ & 5676 & YB-4170 \\
\hline H. henricii Wickerham 1969 & Bird feces & $74-73^{b}$ & 5765 & YB-2194 \\
\hline H. nonfermentans Wickerham 1969 & Creek water & $72-15^{b}$ & 5764 & YB-2203 \\
\hline H. wingei Wickerham $1956 \ldots \ldots$ & Dead conifer & $71-80^{b}$ & 2431 & $\mathrm{Y}-2340$ \\
\hline H. wingei & Dead conifer & $71-78$ & 2432 & $\mathrm{Y}-2340-5^{c}$ \\
\hline H. winge & Dead conifer & $71-79$ & 2433 & $\mathrm{Y}-2340-21^{c}$ \\
\hline H. wingei & $\begin{array}{l}\text { Ips sp. from Picea engel- } \\
\text { mannii }\end{array}$ & $74-76$ & 2430 & Y-1987 \\
\hline H. wingei & Dead conifer & $74-77$ & 5678 & YB-4662 \\
\hline
\end{tabular}

${ }^{a}$ UCD, Department of Food Science and Technology Collection, University of California, Davis, Calif.; CBS, Centraalbureau voor Schimmelcultures, Delft, The Netherlands; NRRL, Northern Regional Research Laboratory, Peoria, Ill.

${ }_{b}$ Type strain.

${ }^{c}$ Haploid mating types derived from Y-2340.

\section{RESULTS}

Nuclear DNA base compositions of the organisms are shown in Table 2. Two clusters of strains were apparent from these data. The first cluster, ranging from 40.3 to $40.8 \mathrm{~mol} \% \mathrm{G}+\mathrm{C}$, included both strains of $H$. canadensis and four strains of $H$. wingei; a fifth strain of $H$. wingei had a slightly but significantly lower $\mathrm{G}+\mathrm{C}$ content $(39.7 \mathrm{~mol} \%)$. The second cluster consisted of the three Pacific Northwest isolates of $H$. alni, with base compositions 1 to $1.5 \mathrm{~mol} \% \mathrm{G}+\mathrm{C}$ higher than those of the yeasts of the $H$. wingei$H$. canadensis subgroup. The two varieties of $H$. bimundalis differed by $2.5 \mathrm{~mol} \% \mathrm{G}+\mathrm{C}$; in our experience (14), a difference of this magnitude precludes significant sequence complementarity. By the same reasoning, we infer that $H$. beckii is not closely related to the other yeasts studied.

The type strain of $H$. wingei (71-80) and a representative strain (68-928A) of $H$. alni were chosen as reference organisms for DNA sequence comparisons. The renaturation kinetics of homologous reference DNA from $H$. wingei are shown in Fig. 1. The Britten-Kohne plot (3) of Fig. 1A shows that the reaction was essentially complete, with $76 \%$ reannealing at $\mathrm{C}_{0} \mathrm{t} 80\left(\mathrm{C}_{0} \mathrm{t}\right.$ $=$ initial nucleotide concentration in moles per liter $\times$ time in seconds $[3,14])$. A modified Wetmur-Davidson plot (19) of the early data
TABLE 2. Base composition of nuclear DNA of 13 strains of the genus Hansenula

\begin{tabular}{|c|c|c|c|}
\hline Organism & $\begin{array}{l}\text { Strain desig- } \\
\text { nation }^{\alpha}\end{array}$ & $\begin{array}{c}\mathrm{G}+\mathrm{C}^{b} \\
\left(\mathrm{~mol}^{\text {\% }}\right)\end{array}$ & $\pm \mathrm{SD}^{c}$ \\
\hline Hansenula beckii & $74-68^{d}$ & 37.1 & 0.29 \\
\hline H. wingei . . . . & $74-76$ & 39.7 & 0.15 \\
\hline H. wingei & $71-79$ & 40.3 & 0.26 \\
\hline$H$. wingei & $71-78$ & 40.4 & 0.25 \\
\hline$H$. canadensis & $74-72$ & 40.4 & 0.26 \\
\hline$H$. wingei $\ldots$ & $71-80^{d}$ & 40.5 & 0.25 \\
\hline H. wingei & $74-77$ & 40.6 & 0.21 \\
\hline H. canadensis & $74-71^{d}$ & 40.8 & 0.12 \\
\hline $\begin{array}{l}H . \text { bimundalis var. } \\
\text { bimundalis }\end{array}$ & $71-33^{d}$ & 41.1 & 0.10 \\
\hline H. alni ... & $68-985$ & (41.8 & 0.25 \\
\hline H. alni & $68-940$ & $\{41.9$ & 0.09 \\
\hline H. $a \ln i$ & $68-928 \mathrm{~A}^{d}$ & 42.0 & 0.36 \\
\hline $\begin{array}{l}H . \text { bimundalis var. } \\
\text { americana }\end{array}$ & $74-69^{d}$ & 43.6 & 0.27 \\
\hline$H$. nonfermentans & $72-15^{d}$ & 45.3 & 0.26 \\
\hline H. henricii ...... & $74-73^{d}$ & 49.6 & 0.11 \\
\hline
\end{tabular}

${ }^{a}$ University of California, Davis, Department of Food Science and Technology Collection strain number.

${ }^{b}$ Calculated from the average of at least four buoyant density determinations. Braces indicate those values which are not separable at the $95 \%$ confidence level (Student-Newman-Keuls a posteriori range test [16]).

SD, Standard deviation.

${ }^{d}$ Type strain. 
points (Fig. 1B) indicates that only about $1 \%$ of the rapidly renaturing sequences remained in the radiolabeled preparation.

Table 3 shows the results of heterologous reannealing reactions with DNA from the type strain of $H$. winge $i$ as a reference. Three strains of $H$. wingei shared at least $90 \%$ sequence complementarity with the reference $H$. wingei strain. The DNA sequences of the diploid $H$. wingei 74-76, which had a comparatively low $\mathrm{G}+\mathrm{C}$ content, have undergone significant divergence from those of the type strain. Nevertheless, single ascospores of this strain, when crossed with spores of opposite mating type of the type strain, produced viable ascospore clones (20). However, no information on the interfertility of the ascosporic clones was reported.

An unexpected finding was that the type strains of $H$. wingei and $H$. canadensis shared substantial relatedness. In another reannealing experiment with $H$. wingei reference DNA (results not shown), the second strain of $H$. canadensis (74-72) was found to be related to the $H$. wingei type by essentially the same value as the type of $H$. canadensis. None of the other yeasts showed significant DNA sequence similarity to H. wingei.

Reannealing reactions with DNA from $H$. alni 68-928A as a reference are shown in Table 4. All three Pacific Northwest strains were virtually indistinguishable by our molecular criterion; only minimal complementarity was noted between these strains and the other yeasts.

\section{DISCUSSION}

Our data indicate that the current classification (20) of the yeasts used in this study is in some cases at variance with the relationships elucidated by molecular means. The various strains of $H$. wingei and $H$. canadensis share

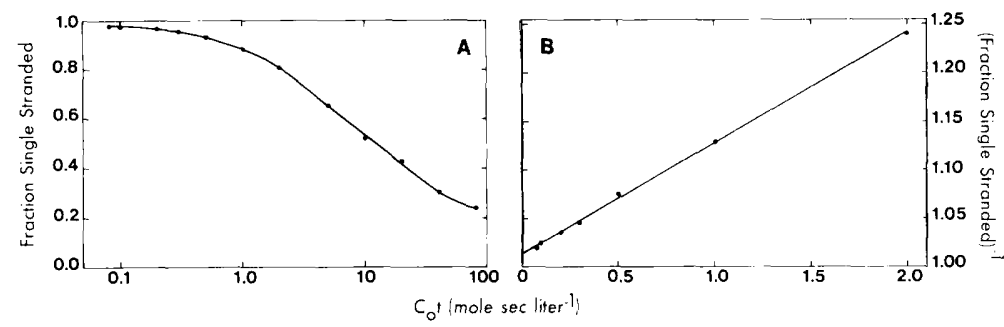

FIG. 1. Reassociation kinetics of $0.2 \mu \mathrm{g}$ of labeled DNA from $\mathrm{H}$. wingei 71-80 with excess unlabeled homologous DNA, in $280 \mathrm{mM}$ phosphate buffer at $64^{\circ} \mathrm{C}$. At various times, $0.5-\mathrm{ml}$ portions in sealed culture tubes were removed, and the degree of duplex formation was assayed by hydroxylapatite fractionation. (A) Data presented by the method of Britten and Kohne (3). (B) Early data points presented in modified secondorder rate plot (19).

TABLE 3. Reannealing $g^{a}$ between labeled DNA from $H$. wingei $71-80$ and DNA from nine strains of yeast

\begin{tabular}{|c|c|c|c|c|}
\hline Organism or tissue & $\begin{array}{c}\text { Strain } \\
\text { designation }\end{array}$ & $\begin{array}{c}\text { Actual } \\
\text { binding } \pm \mathrm{SD}^{c}(\%)\end{array}$ & $\begin{array}{c}\text { Relative } \\
\text { binding }^{d}(\%)\end{array}$ & $\Delta T_{m(e)}^{e}$ \\
\hline Hansenula wingei & $71-80^{f}$ & $76.2 \pm 1.4$ & 100 & \\
\hline H. wingei . . . . & $71-78$ & $74.3 \pm 2.5$ & 97.5 & 0.0 \\
\hline H. wingei & $71-79$ & $73.4 \pm 1.8$ & 96.3 & 0.2 \\
\hline H. wingei & $74-77$ & $69.6 \pm 1.9$ & 91.3 & 1.7 \\
\hline H. canadensis & $74-71^{e}$ & $59.3 \pm 1.2$ & 77.6 & 3.4 \\
\hline H. wingei .... & $74-76$ & $47.8 \pm 2.6$ & 62.2 & 5.2 \\
\hline H. beckii. & $74-68^{e}$ & $7.6 \pm 0.3$ & 8.8 & \\
\hline H. alni. & $68-928 \mathrm{~A}^{e}$ & $5.4 \pm 0.3$ & 5.9 & \\
\hline H. bimundalis var. bimundalis & $71-33^{e}$ & $4.1 \pm 0.5$ & 4.1 & \\
\hline H. bimundalis var americana. & $74-69^{e}$ & $3.4 \pm 0.5$ & 3.2 & \\
\hline Calf thymus . . . . & & $1.2 \pm 0.2$ & 0.3 & \\
\hline
\end{tabular}

${ }^{a 2} \mathrm{P}$-labeled DNA $(0.2 \mu \mathrm{g})$ and unlabeled DNA $(200 \mu \mathrm{g})$ in $0.5 \mathrm{ml}$ of $280 \mathrm{mM}$ PB at $64^{\circ} \mathrm{C}$.

${ }^{b}$ University of California, Davis, Department of Food Science and Technology Collection strain number.

${ }^{c}$ Average of triplicate samples corrected for zero-time binding $=0.23 \% \pm 0.04 \%$.

${ }^{d}$ Corrected for self-renaturation $=1.02 \% \pm 0.17 \%$.

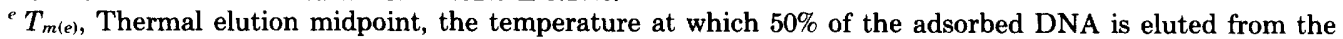
hydroxylapatite. $\Delta T_{m(e)}$, Decrease in $T_{m(e)}$ between the heterologous reaction and the homologous (H. wingei 71$80)$ reaction.

'Type strain. 
TABLE 4. Reannealing $a$ between labeled DNA from $H$. alni 68-928A and DNA from six strains of yeast

\begin{tabular}{|c|c|c|c|c|}
\hline Organism or tissue & $\begin{array}{c}\text { Strain } \\
\text { designation }^{b}\end{array}$ & $\begin{array}{c}\text { Actual } \\
\text { binding } \pm \mathrm{SD}^{r} \\
(\%)\end{array}$ & $\begin{array}{c}\text { Relative } \\
\text { binding } \\
(\%)\end{array}$ & $\left.\Delta T_{m(e)}\right)^{e}$ \\
\hline Hansenula alni & $68-928 \mathrm{~A}^{f}$ & $82.4 \pm 0.46$ & 100 & \\
\hline H. alni & $68-940$ & $80.9 \pm 0.41$ & 98.1 & 0.4 \\
\hline H. alni & $68-985$ & $81.0 \pm 1.06$ & 98.3 & 1.0 \\
\hline H. wingei & $71-80^{e}$ & $9.2 \pm 0.77$ & 9.6 & \\
\hline H. canadensis & $74-71^{e}$ & $8.3 \pm 0.68$ & 8.4 & \\
\hline H. bimundalis var. bimundalis & $71-33^{e}$ & $5.2 \pm 0.25$ & 4.6 & \\
\hline H. bimundalis var. americana & $74-69^{e}$ & $5.2 \pm 0.48$ & 4.6 & \\
\hline Calf thymus $\ldots \ldots \ldots \ldots \ldots$ & & $2.4 \pm 0.04$ & 1.0 & \\
\hline
\end{tabular}

${ }^{a 2}$ P-labeled DNA $(0.2 \mu \mathrm{g})$ and unlabeled DNA $(200 \mu \mathrm{g})$ in $0.5 \mathrm{ml}$ of $280 \mathrm{mM} \mathrm{PB}$ at $64^{\circ} \mathrm{C}$.

${ }^{b}$ University of California, Davis, Department of Food Science and Technology Collection strain number.

${ }^{C}$ Average of triplicate samples, corrected for zero-time binding $=0.27 \pm 0.03$.

${ }^{d}$ Corrected for self-renaturation $=1.55 \% \pm 0.36 \%$.

${ }^{e}$ See footnote $e$ of Table 3 for definition of $\Delta T_{m(e)}$.

${ }^{\prime}$ Type strain.

substantial kinship, although the spectrum of relatedness values observed indicates that the group is somewhat heterogeneous (Table 3). Additional genome comparisons, using a larger number of strains as well as several reference strains, should define the boundaries of the cluster and possible subgroups within it. A comparison among $H$. canadensis strains and the atypical $H$. wingei 74-76 would be of particular interest. Exploratory experiments on electrophoretic mobilities of various enzymes (G. B. Fuson, C. W. Price, and H. J. Phaff, unpublished data) suggest that the electrophoretic patterns of the type strain of $H$. canadensis and $H$. wingei 74-76 resembled each other more closely than they did that of the type strain of $H$. wingei. For the present, it seems reasonable to combine $H$. canadensis and $H$. wingei into a single taxon, $H$. canadensis, with $H$. wingei as a synonym. Because $H$. canadensis was described 5 years earlier than $H$. wingei (Table 1), the name of the former has priority.

Our data (Table 4) show that the Pacific Northwest strains constitute a natural cluster not closely related to any of the other Hansenula strains studied; this supports the proposal (12) that these strains be recognized as a new species, $H$. alni.

A conventional classification (20) based on the then-available phenotypic data (Table 5) of the yeasts studied here does not accurately reflect the natural relationships within the group. For example, $H$. wingei 74-76 is phenotypically indistinguishable from the type strain of $H$. wingei, except that freshly isolated single ascospore clones of opposite sex isolated from strain 74-76 neither agglutinate nor conjugate. However, strain 74-76 has diverged further from the $H$. wingei type strain than has $H$. canadensis, currently classified as a separate species on the basis of its apparently homothallic mating behavior, its ascospore number, and its lack of true hyphae. The phenotypic differences between the closely related $H$. wingei and $H$. canadensis appear no more significant than the differences between $H$. wingei and $H$. alni, yeasts which have little kinship.

The two varieties of $H$. bimundalis differ only in assimilation of $D$-arabinose and in growth at $37^{\circ} \mathrm{C}$ (Table 5); these properties do not adequately reflect the evolutionary distance between these two organisms. The $2.5 \mathrm{~mol} \% \mathrm{G}+\mathrm{C}$ difference in DNA base composition between the two varieties of $H$. bimundalis strongly suggests that they are not members of the same species. Wickerham (20) showed that $H$. bimundalis var. bimundalis conjugates with $H$. bimundalis var. americana but that the zygotes do not produce ascospores. However, before $\mathrm{H}$. $b i$ mundalis var. americana is accorded species status, its possible relationship to other hansenulas of similar base composition should be investigated. Our molecular data also indicate that $H$. beckii has little kinship with the other yeasts surveyed. Thus, the consistent application of classical taxonomic methods can result either in the separation of closely related organisms into different taxa or in the unwarranted combination of organisms which share little filiation.

Although many of the characters listed in Table 5 are considered significant species-specific traits $(9,18)$ and are often employed singly to delimit yeast species, their biological significance is uncertain. Several of the traits listed in Table 5 (e.g., the positive assimilation of $D$-arabinose) can be altered by single mutational events; for others (e.g., spore number, true hyphae formation), the genetic basis and selective forces involved are unknown. As a consequence of the sole dependence on the conventional sys- 


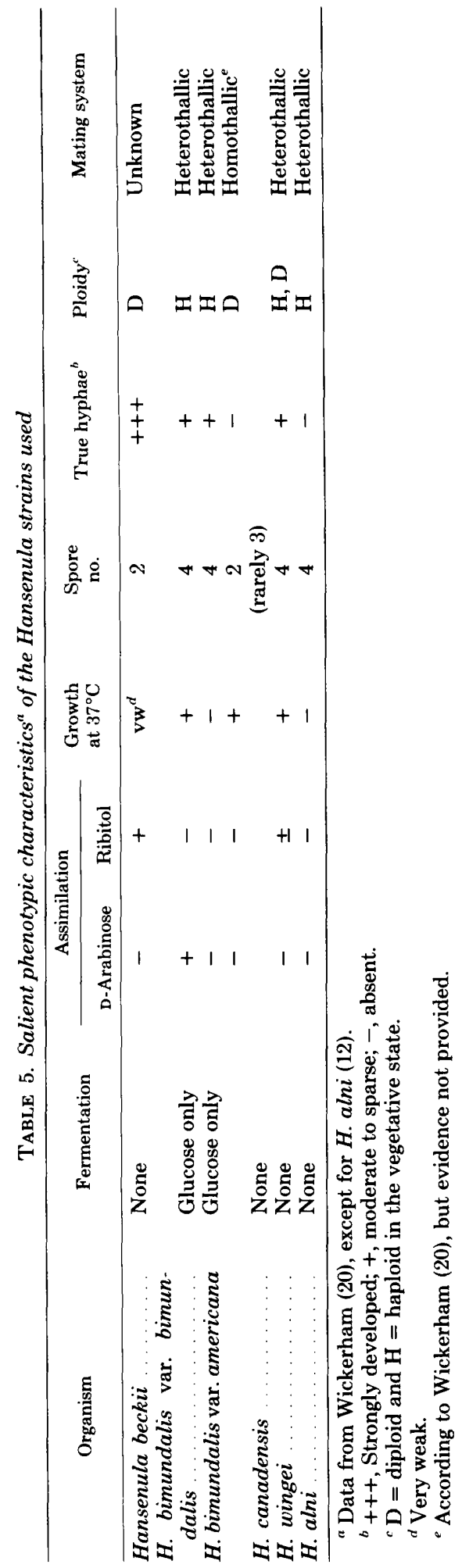

tem, Wickerham (20) separated the genus Hansenula into two major phylogenetic branches on the basis of homo- or heterothallic mating behavior. His classification placed the heterothallic $H$. wingei and $H$. canadensis (which he interpreted as homothallic) on different phylogenetic lines. These yeasts were shown by us to share substantial sequence complementarity. It has been demonstrated that mutation of a single locus in Saccharomyces cerevisiae (7) and Schizosaccharomyces pombe (8) is sufficient to effect a change from heterothallic to homothallic mating behavior. Thus, the distinction between homo- and heterothallism is not a sound basis for species separation.

With the exception of $H$. alni, all of the yeasts included in our survey have been characterized both by numerical analysis of the conventional phenotypic properties and by the proton magnetic resonance spectra and serology of their cell wall mannans. On the basis of Adansonian analysis, Campbell (4) proposed to reduce $H$. wingei, $H$. canadensis, and both varieties of $H$. bimundalis to a single species. Poncet (13), although not suggesting any changes in species assignment, nonetheless placed the same three species together with $H$. beckii into her group $\mathrm{Al}$ as defined by factor analysis. By her criteria, $H$. winge $i$ and $H$. canadensis had high overall phenotypic similarity but not significantly more than that found between the pairs $H$. wingei-H. beckii or $H$. bimundalis var. bimundalis- $H$. bimundalis var. americana. Thus, these two numerical analyses, while recognizing the commonality of $H$. wingei and $H$. canadensis, were not able to distinguish this level of kinship from the other, more distant relationships among the pairs mentioned above. As has been noted elsewhere (14), the lack of congruence between the molecular and numerical approaches probably results from the undue emphasis of numerical methods upon carbohydrate assimilation and fermentations.

Cell wall structures have been proposed as a reliable measure of common ancestry (17); these structures can be compared by several indirect techniques. Gorin and Spencer (5) examined the cell wall mannans of many of these yeasts by proton magnetic resonance spectroscopy. They found that $H$. beckii and $H$. canadensis had quite similar spectra, whereas $H$. wingei and both varieties of $H$. bimundalis shared another pattern. This grouping does not agree with our DNA-determined relationships. A similar disparity was noted earlier for members of the genera Debaryomyces and Pichia (14).

Tsuchiya et al. (17) found that $H$. wingei, $H$. canadensis, and $H$. beckii had indistinguishable cell surface antigens. The antigenic structures of 
the two varieties of $H$. bimundalis were found to be similar to each other but different from those of the $H$. wingei group. The observed antigenic similarities between $H$. beckii and $H$. canadensis were not confirmed by our molecular data and are likely the result of evolutionary convergence. In addition, it has been demonstrated by Ballou (1) and co-workers that in Saccharomyces the syntheses of several immunochemical determinants in the mannan of the cell wall are determined by single gene products.

It is clear that the presently available methods of yeast systematics cannot reliably define the natural species of Hansenula that have been identified by genome comparison. Similar observations for other groups of yeasts (14) led us to propose several alternative approaches to provide more significant systematic criteria. Two of these suggestions, an expanded nutritional screening and ecological investigations, find further support here. It is suggestive that $H$. alni, although phenotypically similar to the other yeasts studied (Table 5), is the only member of this group which has its habitat associated with deciduous (12) rather than coniferous trees. The basis of this ecological specialization could prove to be taxonomically significant. Nutritional studies may also be useful to differentiate natural clusters within this group. Hedrick and Dupont (6) have shown that many Hansenula species can use single amino acids as sources of carbon and nitrogen. H. bimundalis var. americana was able to assimilate alanine, aspartate, glutamate, proline, and serine. $H$. bimundalis var. bimundalis, $H$. canadensis, and $H$. winge $i$ assimilate all of these except serine, whereas $H$. beckii assimilates only glutamate and proline. These data suggest that a survey of the organic compounds metabolized by yeasts as sole sources of carbon or nitrogen, particularly those dissimilated via peripheral pathways, could reveal numerous meaningful phenotypic differences.

\section{ACKNOWLEDGMENTS}

This research was supported by Public Health Service Research grant GM-16307.08 from the National Institute of General Medical Sciences.

We gratefully acknowledge the capable assistance of Nancy Krauter in the DNA isolation and of Mary Miranda for diagnostic testing. We thank C. P. Kurtzman for supplying several of the yeast strains and for helpful discussions. We are indebted to Duane Brown for providing the Beckman model E ultracentrifuge.

\section{REPRINT REQUESTS}

Address reprint requests to: $H$. J. Phaff, Department of Food Science and Technology, University of California, Davis, CA 95616.

\section{LITERATURE CITED}

1. Ballou, C. E. 1974. Some aspects of the structure, immunochemistry, and genetic control of yeast mannans. Adv. Enzymol. 40:239-270.

2. Brenner, D. J., G. R. Fanning, A. Rake, and K. E. Johnson. 1969. A batch procedure for thermal elution of DNA from hydroxyapatite. Anal. Biochem. 28: 445-459.

3. Britten, R. J., and D. E. Kohne. 1968. Repeated sequences in DNA. Science 161:529-540.

4. Campbell, I. 1973. Numerical analysis of Hansenula, Pichia and related yeast genera. J. Gen. Microbiol. 77: 427-441.

5. Gorin, P. A. J., and J. F. T. Spencer. 1970. Proton magnetic resonance spectroscopy - an aid in identification and chemotaxonomy of yeasts. Adv. Appl. Microbiol. 13:25-89.

6. Hedrick, L. R., and P. D. Dupont. 1968. The utilization of L-amino acids as carbon source by yeasts of the genera Hansenula and Trichosporon. Antonie van Leeuwenhoek J. Microbiol. Serol. 34:465-473.

7. Hicks, J. B., and I. Herskovitz. 1976. Interconversion of yeast mating types. I. Direct observations on the action of the homothallism (HO) gene. Genetics 83: 245-258.

8. Leupold, U. 1950. Die Vererbung von Homothallie und Heterothallie bei Schizosaccharomyces pombe. C. R. Trav. Lab. Carlsberg Ser. Physiol. 24:381-480.

9. Lodder, J. 1970. General classification of the yeasts, p. 133. In J. Lodder (ed.), The yeasts-a taxonomic study. North-Holland Publishing Co., Amsterdam.

10. Mendonça-Hagler, L. C., and H. J. Phaff. 1975. Deoxyribonucleic acid base composition and deoxyribonucleic acid/deoxyribonucleic acid hybrid formation in psychrophobic and related yeasts. Int. J. Syst. Bacteriol. 25:222-229.

11. Meyer, S. A., K. Anderson, R. E. Brown, M. T. Smith, D. Yarrow, G. Mitchell, and D. G. Ahearn. 1975 Physiological and DNA characterization of Candida maltosa, a hydrocarbon utilizing yeast. Arch. Microbiol. 104:225-231.

12. Phaff, H. J., M. W. Miller, and M. Miranda. 1979 Hansenula alni, a new heterothallic species of yeast from exudates of alder trees. Int. J. Syst. Bacteriol. 29: 60-63.

13. Poncet, S. 1970. Le Genre Hansenula, H. et P. Sydow (Ascomycetes, Endomycetaceae). Application d'une Méthode d'analyse Factorielle à la Taxinomie de ce Groupe. Ann. Inst. Pasteur (Paris) 119:232-248.

14. Price, C. W., G. B. Fuson, and H. J. Phaff. 1968. Genome comparison in yeast systematics: delimitation of species within the genera Schwanniomyces, Saccharomyces, Debaryomyces, and Pichia. Microbiol. Rev. 42:161-193.

15. Schildkraut, C. L., J. Marmur, and P. Doty. 1962. Determination of the base composition of deoxyribonucleic acid from its buoyant density in $\mathrm{CsCl}$. J. Mol. Biol. 4:430-433.

16. Sokal, R. R., and F. J. Rohlf. 1969. Biometry; the principles and practice of statistics in biological research. W. H. Freeman and Co., San Francisco.

17. Tsuchiya, T., Y. Fukazawa, M. Taguchi, T. Nakase, and T. Shimoda. 1974. Serological aspects of yeast classification. Mycopathol. Mycol. Appl. 53:77-91.

18. van der Walt, J. P. 1970. Criteria and methods used in classification, p. 34-113. In J. Lodder (ed.), The yeastsa taxonomic study. North-Holland Publishing Co., Amsterdam.

19. Wetmur, J. G., and N. Davidson. 1968. Kinetics of renaturation of DNA. J. Mol. Biol, 31:349-370.

20. Wickerham, L. J. 1970. Hansenula H. et P. Sydow, p. 226-315. In J. Lodder (ed.), The yeasts-a taxonomic study. North-Holland Publishing Co., Amsterdam. 